\title{
Penerapan Model Problem Based Learning Untuk Meningkatkan Partisipasi dan Hasil Belajar IPS-1 Mahasiswa PGSD Universitas Palangka Raya
}

\author{
Roso Sugiyanto \\ PGSD, FKIP, Universitas Palangka Raya, Kalimantan Tengah \\ rososugiyanto@gmail.com
}

\begin{abstract}
Abstrak
Penelitian ini bertujuan untuk meningkatkan partisipasi dan hasil belajar mahasiswa dalam perkuliahan IPS-1 serta mendeskripsikan tanggapan mahasiswa terhadap penerapan model pembelajaran berbasis masalah (problem based learning). Penelitian ini menggunakan desain penelitian tindakan kelas yang dilakukan pada semester ganjil tahun 2018/2019 dengan jumlah mahasiwa 42 orang. Teknik pengumpulan data dengan observasi, kuesioner, dan tes hasil belajar kemudian dianalisis dengan metode analisis deskriptif. Hasil penelitian menunjukkan bahwa penerapan model pembelajaran berbasis masalah (problem based learning) 1) meningkatkan aktivitas (partisipasi) mahasiswa dalam Kegiatan Belajar Mengajar (KBM) 2) meningkatkan hasil belajar mata kuliah IPS-1 nilai rata-rata pre-test sebesar 58 meningkat setelah selesainya pelaksanaan tindakan menjadi rata-rata 78 dan 3) mendapat respon yang positif dari mahasiswa karena pembelajaran menjadi lebih bermakna.
\end{abstract}

Kata-kata kunci: Problem Based Learning, Partisipasi, Hasil Belajar

\section{Pendahuluan}

Perkembangan teknologi informasi melahirkan ribuan informasi setiap hari, informasi yang ada tidak semua berdampak positif akan tetapi dapat pula mengandung informasi yang berpengaruh buruk. Mahasiswa adalah salah satu pihak yang di tuntut membangun kemampuan pengolahan informasi yang memadai. Keterampilan dan kemampuan untuk mencermati dan mengakses informasi yang baik bagi dirinya merupakan bekal untuk dapat menganalisa berbagai informasi yang terus berkembang dan memenuhi beranda media masa.

Keberhasilan atau kegagalan pembelajaran tergantung dari baik dan tidaknya interaksi dan kerjasama antar komponen yang terlibat di dalamnya. Dengan demikian proses pembelajaran dapat berjalan efektif apabila semua komponen/faktor yang berpengaruh dalam proses pembelajaran saling mendukung dalam rangka mencapai tujuan pembelajaran. Hal ini berarti bahwa proses pembelajaran merupakan komponen terpenting yang dapat diubah/dimanipulasi dengan mengembangkan segala sesuatu yang ada.

Penggunaan metode ceramah yang dominan dipergunakan dalam pembelajaran IPS-1 selama ini diarahkan pada learning to know, permasalahan yang disampaikan cenderung bersifat akademik (book oriented) tidak mengacu pada masalah-masalah kontektual yang dekat dengan kehidupan mahasiswa sehingga hal tersebut menyebabkan pembelajaran IPS-1 menjadi kurang 
bermakna bagi mahasiswa. Ini tampak pada rendahnya partisipasi mahasiswa dalam kegiatan belajar.

Untuk mengatasi masalah tersebut, perlu dilakukan suatu upaya penyelesaian yaitu dengan menerapkan suatu model pembelajaran yang memungkinkan terjadinya kegiatan belajar mengajar yang kondusif dan memperkaya pengalaman belajar mahasiswa. Pengalaman belajar diperoleh melalui keterlibatan mahasiswa secara langsung dalam serangkaian kegiatan untuk mengeksplorasi pengetahuan yang ada dan interaksi dengan materi pelajaran, teman, nara sumber serta sumber belajar lainnya. Selanjutnya mahasiswa mengkontruksi pengetahuannya sendiri berdasarkan pengalaman belajar yang diperolehnya.

Kegiatan belajar dalam perkuliahan IPS-1 dengan menerapkan model pembelajaran berbasis masalah (problem based learning/PBL) didesain dengan mengkonfrontasikan mahasiswa dengan masalah-masalah kontekstual yang berhubungan dengan materi perkuliahan sehingga mahasiswa mengetahui mengapa mereka belajar kemudian mengidentifikasi dan mengumpulkan informasi dari buku sumber, diskusi dengan teman untuk dapat mencarikan solusi masalah yang dihadapinya. Penelitian tindakan kelas ini untuk menjawab permasalahan pokok, yaitu 1) Apakah penerapan model PBL dapat meningkatkan partisipasi mahasiswa dalam perkuliahan IPS-1? 2) Apakah penerapan model PBL dapat meningkatkan prestasi belajar mahasiswa dalam perkuliahan IPS-1?

Pembelajaran berbasis masalah dikenal dengan istilah problem based learning (PBL), Alder dan Milne (1997:195) mendefinisikan PBL dengan metoda yang berfokus kepada identifikasi permasalahan serta penyusunan kerangka analisis dan pemecahan. Metoda ini dilakukan dengan membentuk kelompok-kelompok kecil, banyak kerja sama dan interaksi, mendiskusikan hal-hal yang tidak atau kurang dipahami serta berbagi peran untuk melaksanakan tugas dan saling melaporkan.

Menurut Tan (2003:30) bahwa PBL memiliki karakteristik: (1) masalah digunakan sebagai awal pembelajaran, (2) masalah yang digunakan merupakan masalah dunia nyata, (3) masalah menuntut perspektif majemuk, (4) masalah membuat siswa merasa tertantang untuk mendapatkan pembelajaran di ranah pembelajaran yang baru, (5) mengutamakan belajar mendiri, (6) memanfaatkan sumber pengetahuan yang bervariasi, dan (7) pembelajarannya kolaboratif, komunikatif, dan kooperatif.

Selanjutnya Heller (1992) mengemukakan keberhasilan pendekatan PBL tergantung pada dua faktor, yaitu: (1) jenis masalah yang dikonfrontasikan kepada mahasiswa yaitu masalah yang menuntut pemecahan berdasarkan PBL, dan (2) Formasi dan kebermanfaatan fungsi kelompok untuk memaksimalkan aktivitas dan partisipasi mahasiswa secara keseluruhan. 


\section{Metode Penelitian}

Penelitian ini merupakan penelitian tindakan kelas (classroom action research) yang sengaja dilakukan untuk merencanakan, melaksanakan kemudian mengamati dampak dari pelaksanaan tindakan tersebut pada subyek penelitian. Penelitian dilakukan melalui dua siklus tindakan dimana masing-masing siklus terdiri dari tahap perencanaan, pelaksanaan tindakan, observasi dan refleksi untuk mengambil keputusan dalam pelaksanaan siklus berikutnya. Adapun subyek dari penelitian ini adalah mahasiswa PGSD kelas B sebanyak 42 mahasiswa semester ganjil. Sedangkan obyeknya adalah penerapan model PBL untuk meningkatkan partisipasi dan hasil belajar IPS-1 mahasiswa.

Teknik pengumpulan data yang dipergunakan dalam penelitian ini disesuaikan dengan jenis data yang diperlukan seperti di tunjukkan pada Tabel berikut ini.

\begin{tabular}{|l|l|l|}
\hline \multicolumn{1}{|c|}{ Data } & \multicolumn{1}{|c|}{ Teknik Pengumpulan } & \multicolumn{1}{c|}{ Instrumen } \\
\hline Partisipasi mahasiswa & Observasi & Pedoman observasi \\
\hline Prestasi Belajar & Tes & Tes hasil belajar \\
\hline Tanggapan mahasiswa & Angket dan wawancara & $\begin{array}{l}\text { Pedoman wawancara dan } \\
\text { kuesioner }\end{array}$ \\
\hline
\end{tabular}

\section{Hasil dan Pembahasan}

Pada siklus I dilakukan sebanyak tiga kali pertemuan dengan materi yang berbeda. Hasil observasi mengenai aktivitas mahasiswa dalam kegiatan pembelajaran IPS-1 pada siklus 1, menunjukkan bahwa, a) Proses komunikasi masih lambat dimana mahasiswa masih malu-malu untuk mengeluarkan pendpatnya sehingga banyak waktu lengang/diam tidak ada yang berbicara dalam diskusi hingga 10 menit. Untuk mengatasi hal tersebut dosen masih banyak memberikan arahan dan bimbingan agar diskusi tetap jalan. b) Kepekaan sosial masih rendah dan pembelajaran masih banyak berjalan secara konvensional dengan dominasi peran dosen yang masih cukup banyak. c) Sikap individual mahasiswa masih dominan, karena mahasiswa belum terbiasa mengemukakan pendapat dan menghargai pendapat teman. d) Kemampuan prediksi dan bernalar mahasiswa masih rendah karena kurangnya kemampuan mahasiswa dalam menginterpretasikan dan mengaplikasikan pengetahuan dan pengalaman belajar yang telah dimiliki. e) Penerapan model PBL telah menunjukkan peningkatan hasil belajar mahasiswa dari nilai rata-rata pre-test 58 menjadi 63 (nilai post-test pada akhir siklus I).

Berdasarkan hasil belajar dan observasi tindakan pada siklus I dilakukan refleksi yang lebih menekankan pemberian stimulus kepada mahasiswa untuk berani mengemukakan pendapat/gagasan. Mahasiswa diberi kesempatan seluas-luasnya untuk berargumentasi dengan hipotesa-hipotesa dan asumsi-asumsi tertentu. Peran dosen sebagai fasilitator yaitu memberikan arahan bila proses pemecahan masalah mendapat hambatan dalam mencapai tujuan pembelajaran. 
Pelaksanaan tindakan siklus kedua berjalan lancar, pembelajaran semakin kondusif. Secara fisik maupun mental mahasiswa lebih siap dibandingkan dengan pelaksanaan siklus pertama. Keadaan seperti tersebut sangat membantu kelancaran dalam proses belajar.

Kondisi perkuliahan pada siklus kedua ini menunjukkan bahwa: a) Kemampuan bertanya dan menjawab sudah baik dilihat dari jumlah mahasiswa yang aktif maupun bobot pertanyaan dan jawaban yang diberikan. Terjadi komunikasi yang timbal balik secara terbatas namun belum mampu menyangga pendapat secara lebih luas dan tajam berdasarkan pengalaman belajar yang telah dimilikinya. Peningkatan yang terjadi bahwa mahasiswa telah berani mengemukakan gagasannya dan lebih menguasai permasalahan yang dibahas sehingga suasana perkuliahan lebih demokratis dibandingkan dengan siklus satu. b) Mahasiswa telah mampu menggali contoh-contoh nyata dalam masyarakat sehubungan dengan permasalahan yang dibahas walaupun upaya dalam mengungkapan fenomena-fenomena yang ada di masyarakat belum sistematis. c) Kemampuan merumuskan hasil diskusi sudah lebih baik tetapi belum optimal dimana wawasan mahasiswa perlu ditingkatkan, sehingga mahasiswa belum mampu melakukan prediksi-prediksi masa depan dengan lebih akurat berdasarkan data dan fakta. d) Dosen telah mulai mengurangi perannya dalam memberikan arahan dan bimbingan, tetapi lebih banyak memberikan kesempatan yang seluasluasnya kepada mahasiswa untuk berargumentasi memanfaatkan waktu, ruang, fasilitas baik secara individu maupun kelompok. e) Dilihat dari hasil belajar mahasiswa juga terjadi peningkatan yaitu rata-rata pre-test 64 dan nilai post-test 78 .

Berdasarkan hasil belajar dan observasi tindakan siklus kedua dilakukan refleksi dengan menstimulus mahasiswa untuk aktif dalam KBM secara merata (keseluruhan) dan meningkatkan kemampuan prediksi masa depan dengan asumsi-asumsi yang dirumuskan sehingga solusi permasalahan menjadi lebih akurat. Hasil di atas sesuai dengan penelitian Celik, Onder \& Silay (2011) yang menunjukkan bahwa PBL sangat efektif meningkatkan prestasi pelajaran fisika dan penelitian Achmad Yoesoef (2015) bahwa penerapan model problem based learning dapat meningkatkan kemampuan menanya dan penguasaan konsep fisika.

Respon (tanggapan) mahasiswa dengan angket tentang tanggapan mahasiswa terhadap penerapan model PBL, disusun untuk mengetahui pendapat mahasiswa tentang KBM yang dialami dan dirasakan dalam perkuliahan IPS-1. Penerapan model pembelajaran ini mendapat respon yang positif dari mahasiswa, lebih rinci tanggapan mahasiswa terhadap penerapan model PBL terlihat pada tabel di bawah ini. 


\begin{tabular}{|l|l|l|l|l|l|l|}
\hline No. & Pernyataan & $\begin{array}{l}\text { Sangat } \\
\text { Setuju }\end{array}$ & Setuju & $\begin{array}{l}\text { Ragu- } \\
\text { Ragu }\end{array}$ & $\begin{array}{l}\text { Tidak } \\
\text { Setuju }\end{array}$ & $\begin{array}{l}\text { Sangat } \\
\text { Tidak Setuju }\end{array}$ \\
\hline 1. & $\begin{array}{l}\text { Lebih mudah memahami materi karena } \\
\text { dihubungkan dengan masalah dan contoh } \\
\text { nyata pada masyarakat }\end{array}$ & $30 \%$ & $65 \%$ & $5 \%$ & & \\
\hline 2. & Pembelajaran menjadi lebih bermakna & $25 \%$ & $65 \%$ & $10 \%$ & & \\
\hline 3. & $\begin{array}{l}\text { Menemukan konsep dan contoh-contoh } \\
\text { sendiri dalam memecahakan permasalahan. }\end{array}$ & $35 \%$ & $65 \%$ & & & \\
\hline 4. & $\begin{array}{l}\text { Lebih tertantang untuk belajar atau } \\
\text { memecahkan masalah. }\end{array}$ & $55 \%$ & $45 \%$ & & & \\
\hline 5. & $\begin{array}{l}\text { Melatih kemampuan berbicara di depan } \\
\text { forum. }\end{array}$ & $90 \%$ & $10 \%$ & & & \\
\hline 6. & $\begin{array}{l}\text { Melatif kemampuan menghargai pendapat } \\
\text { teman }\end{array}$ & $95 \%$ & $5 \%$ & & & \\
\hline 7. & $\begin{array}{l}\text { Menjadi lebih semangat untuk mengikuti } \\
\text { pembelajaran/ perkuliahan }\end{array}$ & $20 \%$ & $70 \%$ & $10 \%$ & & \\
\hline
\end{tabular}

Berdasarkan tabel hasil angket di atas yang diberikan kepada maahsiswa tentang pendapatannya terhadap penerapan model pembelajaran PBL hampir semuanya menyatakan positif atau setuju karena merasa puas dan pembelajaran menjadi lebih bermanfaat.

\section{Simpulan}

Berdasarkan hasil penelitian dan pembahasan pelaksanaan tindakan maka dapat di simpulkan sebagai berikut.

1. Penerapan model PBL dapat meningkatkan aktivitas mahasiswa dalam kegiatan belajar mengajar mata kuliah IPS-1.

2. Penerapan model PBL dapat meningkatkan hasil belajar mahasiswa dalam mata kuliah IPS1 yang ditunjukkan oleh nilai rata-rata pre-test sebesar 58 meningkat setelah selesainya pelaksanaan tindakan menjadi rata-rata 78 .

3. Penerapan model pembelajaran berbasis masalah mendapat respon (tanggapan) yang positif dari mahasiswa karena dengan model ini mahasiswa dapat mengeksplorasi pengetahuan awalnya, bernalar untuk memecahkan masalah sehingga perubahan layanan menjadi sangat bermakna dalam hidupnya.

\section{Daftar Pustaka}

Achmad Yoesoef. 2015. Penerapan Model Problem Based Learning Untuk Meningkatkan Kemampuan Menanya Dan Penguasaan Konsep Fisika Kelas X Mia 1 Sma Negeri 2 Kediri. Jurnal PINUS (Vol. 1, 2015): 96-102.

Adler, Ralph W. and Milne, Markus J. 1997. Improving The Quality of Accounting Students' Learning Through Action-Oriented Learning Tasks. Accounting Education. Vol. 6 No. 3: 191-215. 
Celik, P., Onder, F., \& Silay, I. 2011. The Effect of Problem Based Learning on Students' Success in Physics Course. Procedia-Social and Behavorial Sciences. 28(2011):656-660

Heller, P. 1992. Teaching problem solving through coperative gruoping part, group and individual problem solving. American Journal of Physics. July 1992

Tan, O. S. 2003. Problem Based Learning Innovation:Using Problems to Power Learning in the 21st Century. Singapore:Cengage Learning Asia Pte Ltd. 